\title{
A Comparison of Lumbosacral Kinematics during Prolonged Sitting in Non-specific Chronic Low Back Pain Subgroups; a cross-sectional study
}

Research article

Keywords:

Posted Date: October 9th, 2020

DOI: https://doi.org/10.21203/rs.2.13079/v2

License: (c) (i) This work is licensed under a Creative Commons Attribution 4.0 International License.

Read Full License 


\section{Abstract}

The authors have requested that this preprint be withdrawn due to author disagreement.

\section{Full Text}

The authors have withdrawn this preprint from Research Square. 